\title{
THE RELATIONSHIP OF STUDENTS' EMOTIONAL INTELLIGENCE AND THE LEVEL OF THEIR READINESS FOR ONLINE EDUCATION: A CONTEXTUAL STUDY ON THE EXAMPLE OF UNIVERSITY TRAINING IN SAUDI ARABIA
}

\author{
Ahmed M. Alenezi \\ Northern Border University, Arar, Saudi Arabia. \\ E-mail:ahmed.alenezi@nbu.edu.sa
}

\begin{abstract}
Introduction. It is well known that the effectiveness of students' online education depends largely on their skills to interact with the digital educational environment. At the same time, there has been a marked shift in scientific publications from the traditional point of view about the priority of competency formation in students to use educational information and communication technologies on the other aspects of online education, including psychometric.

The aim of this research was to investigate the influence of students' emotional intelligence on their preparedness for online learning programmes.

Methodology and research methods. A questionnaire survey was employed as the main tool. In the course of the questionnaire survey, Emotional Intelligence Scale (EIS) and Online Learning Readiness Scale (OLRS) were used to measure the selected characteristics of students. The method of single-factor dispersion analysis ANOVA (analysis of variance) and t-test of equal dispersions were applied to process the obtained empirical data.

Results and scientific novelty. 340 Saudi students, admitted into the Faculties of Pharmacy, IT, Sciences and Arts in Northern Border University (Arar), took part in the questionnaire. The sample of respondents was random; only 208 respondents fully completed the survey. The gender of students was considered as a key variable. It was revealed that the level of emotional intelligence in female students is higher than in their male fellow students, which ultimately caused the best readiness of girls for online training. The analysis of the survey data showed the variance between the measured respondents' characteristics depending on the area of specialisation. If compared with the Sciences and Arts students, the representatives of the Faculties IT and Pharmacy demonstrated higher level skills to undertake online training, more expressed skills of self-control and computer self-
\end{abstract}


efficacy. The level of online communication self-efficacy, recorded among the respondents, was not so significant. However, the respondents of all four faculties demonstrated a high level of motivation for independent online learning activities. It was reliably established that a high level of emotional intelligence correlates with readiness for such forms of work.

It was found out that students are not always able to clearly identify their educational needs on their own and to understand them without someone's assistance, new arsenal of educational tools, their adequate application and quality. In addition, the emotional attitude to online learning is very significant. Therefore, in order to make e-learning effective, it is appropriate to conduct pre-diagnostics, taking into account students' psychometric parameters, to identify students' expectations about the online courses and to assess own readiness for such training. According to the author of the current publication, pedagogical support of the process of formation and development of emotional intelligence and formation of students' skills to regulate their feelings should become an integral part of the curriculum to ensure the success of the learning process. The author identified the critical points of teaching staff activity, which may vary depending on the required scale of the pedagogical intervention and the specific direction of training.

Practical significance. The research results can be useful for teachers and administrators of educational institutions engaged in the development and promotion of distance and blended learning.

Keywords: emotional intelligence, online learning readiness, e-learning, Saudi Arabia, education.

Acknowledgements. The present research was performed thanks to the grant from the Institute of Scientific Research of the Northern Border University (Arar, Saudi Arabia), within the framework of the project "Assessment of Students' Emotional Intelligence and its Relationship with their Preparedness for Educational Technologies: A Contextual Study of Saudi Arabia" (project No. EAR-2018-39-F-7942).

For citation: Alenezi A. M. The relationship of students' emotional intelligence and the level of their readiness for online education: A contextual study on the example of university training in Saudi Arabia. The Education and Science Journal. 2020; 4 (22): 89-109. DOI: 10.17853/1994-5639-2020-4-89-109 


\title{
ВЗАИМОСВЯЗЬ ЭМОЦИОНАЛЬНОГО ИНТЕЛЛЕКТА СТУДЕНТОВ И УРОВЕНЬ ИХ ГОТОВНОСТИ К ОНЛАЙН- ОБРАЗОВАНИЮ: КОНТЕКСТНОЕ ИССЛЕДОВАНИЕ НА ПРИМЕРЕ ОБУЧЕНИЯ В УНИВЕРСИТЕТЕ В САУДОВСКОЙ АРАВИИ
}

\author{
Ахмед М. Аленези \\ Северный пограничный университет, Арар, Саудовская Аравия. \\ E-mail:ahmed.alenezi@nbu.edu.sa
}

Аннотаиия. Введение. Хорошо известно, что эффективность обучения студентов в режиме онлайн во многом зависит от их навыков и умений взаимодействовать с цифровой образовательной средой. Вместе с тем в научных публикациях последнего времени заметно смещение акцента с традиционной точки зрения о приоритетности формирования компетентности обучающихся в использовании учебных информационно-коммуникационных технологий на другие аспекты онлайн-образования, в том числе психометрические.

Целью изможенного в статье исследования было изучение влияния эмоционального интемлекта студентов на их готовность успешно осваивать университетские программы в онлайн-формате.

Методы и методики. Основным инструментарием предпринятого изыскания служил анкетный опрос, в ходе которого дмя измерения выделенных характеристик обучающихся использовались "Шкала эмоционального интелмекта" (EIS) и "Шкала готовности к онлайн-обучению" (OLRS). Обработка полученных эмпирических данных производияась с привлечением метода однофакторного дисперсионного анализа ANOVA (analysis of variance) и t-теста равных дисперсий.

Результаты и научная новизна. Всего в анкетировании приняли участие 340 саудовских студентов Северного пограничного университета (Арар), обучающихся на четырех факультетах: фармацевтическом, информационных технологий (ИТ), фундаментальных наук и гуманитарных наук. Выборка испытуемых была случайной, полностью ответили на вопросы только 208 респондентов. В качестве одной из ключевых переменных рассматривался пол учащихся. Выяснимось, что уровень эмоционального интемлекта у студенток выше, чем у их сокурсников мужского пола, этим в конечном счете была обусловлена цучшая готовность девушек к онлайн-обучению. Анализ данных опроса показал дисперсию между измеряемыми характеристиками респондентов в зависимости от профиля специализации. Большие способности к онлайн-обучению, более выраженные умения и навыки самоконтроля и компьютерной самоэффективности проде- 
монстрировали представители факультетов "ИТ" и "Фармацевтика", в сравнении со студентами двух других факультетов. Зафиксированный у испытуемых уровень самоэффективности онлайн-общения был не столь значимым. Однако у респондентов всех четырех факультетов выявлена устойчивая повышенная мотивация к самостоятельной учебной онлайн-деятельности. Достоверно установлено, что высокий уровень эмоционального интемлекта коррелирует с готовностью к подобной форме работы.

Обнаружилось, что учащиеся далеко не всегда могут самостоятельно четко обозначить свои образовательные потребности и разобраться, не прибегая к сторонней помощи, в новом арсенале средств обучения, их адекватном применении и качестве. Кроме того, весьма важен эмоциональный настрой на учебу в режиме онлайн. Поэтому, для того чтобы сделать электронное обучение действенным и результативным, целесообразна предварительная диагностика с учетом психометрических параметров обучающихся, выявмением их ожиданий от онлайн-курсов и оценкой степени их готовности к такому обучению. Дия обеспечения его успешности необходимы педагогическое сопровождение процесса становления и развития эмоционального интелмекта и формирование у студентов навыков регулирования своих чувств, которое, по мнению автора публикации, должно стать неотъемлемой частью учебной программы. Намечены критические точки данной деятельности преподавательского состава, которые могут варьироваться в зависимости от требующегося масштаба педагогического вмешательства и специфики направления подготовки.

Практическая значимость. Результаты исследования будут полезны педагогам и администраторам образовательных учреждений, занимающимся разработкой и продвижением технологий дистанционного и смешанного обучения.

Ключевые слова: эмоциональный интемлект, готовность к онлайн-обучению, эмектронное обучение, Саудовская Аравия, образование.

Благодарности. Исследование выполнено благодаря гранту, полученному от Института научных исследований Северного пограничного университета (Арар, Саудовская Аравия), в рамках реализации проекта "Оценка эмоционального интемлекта студентов и его взаимосвязь с их готовностью к образовательным технологиям: контекстное исследование Саудовской Аравии» (проект № EAR-2018-3-9-F-7942).

Для иитирования: Аленези А. М. Взаимосвязь эмоционального интелмекта студентов и уровня их готовности к онцайн-образованию: контекстуальное исследование на примере университетского обучения в Саудовской Аравии // Образование и наука. 2020. Т. 22, № 4. С. 89-109. DOI: 10.17853/ 1994-5639-2020-4-89-109

Образование и наука. Том 22, № 4. 2020/The Education and Science Journal. Vol. 22, № 4. 2020 


\section{Introduction}

There is no dearth of literature wherein the scholars have established the importance of emotion in a face to face classroom setting or in distance mode of learning [1-5]. Many earlier studies found that learning process does not involve only fact or information seeking activities or a practical application of processes. Socio-cognitive approach $[6,7]$ and appraisal theories have defined emotion as monitoring device to assess the achievement and serve as effective tool in meeting the desired goals. Thus, emotions are viewed as internal states of being which encompasses the psychological and psychometric aspects of learners' behaviours which regulate or influence the nature of learning a lot. Though multimedia programmes have been used to improve children's reading, mathematics, spellings and other cognitive processes such as memory and attention too, there is enough evidences that supports its effectiveness in the other domains of learning as well $[8,9]$. The number of studies suggest that social emotional learning (SEL, hereafter) programmes have hardly used technologies as tools of learning [10, 11]. Various international organisations have initiated the process of incorporating technology driven learning in SEL practices [12]. Technologies enhance self-directed learning and boost learners' confidence and freedom of learning at their own pace. Technology driven learning has been proved to be very instrumental in developing emotional intelligence of the learners as well [13].

Online learning has attracted a large number of students in the recent years, be it full time or part time, as it gives flexibility, an exciting learning experience and learners' control over the learning process $[14,15]$. In terms of quality of education, teachers and learners' performance in the learning environments and the quality of infrastructure, though e-learning has revalorised the education process but has caused lot of concerns at local as well as international levels. In this context, learners' preparedness for the digital learning environment and their readiness to explore the maximum utilisation of the resources can definitely reduce these concerns. In most of the earlier studies, learners' abilities to use technology in their academic pursuit were often related to their preparedness for e-learning. While Warner, Christie and Choy proposed learners' readiness as combination of their competence, confidence in using electronic communication, their comfort with online transactions and their ability to fit in independent learning. Smith [16], Smith, Murphy, Mahoney [17] and Lynch [18] related learners' readiness for e-learning with comfort and their ability to managing learning process. 
The present study is based on the idea of learners' readiness as proposed by Hung, Chou, Chen and Own [19]. According to them, besides computer/internet and online communication self-efficacy, learners' potential for self-directed learning, control and motivation for learning are also crucial factors should be take into account while studying learners' readiness for e-learning. These issues have not only prepared the ground more in-depth study in this field but have added psychological perspectives as well. Since learners' responses fluctuate so the technical and non-technical factors that have potential to enhance their readiness to e-learning of the courses and excel, have been taken care of well in this research [20, 21]. In this research, I have explored the role of emotional intelligence (EI, hereafter) in explaining learners' readiness for online learning transactions in the context of Saudi Arabia.

\section{Literature Review}

The importance of emotions has been identified in face to face and distance educational situations. Learning process does not happen in isolation of emotions or emotional considerations and aims to disseminate information or facts or step by step application of procedures only; rather there are socio-cognitive and appraisal [22] theories which propose that emotions act as monitoring device to assess the nature of learning and foster learners' goals. Therefore, emotions are the constructs of internal states (cognitive, psychological, motivational and expressive, feelings) which may result in positive learning results as well as negative learning outcomes [23]. Other scholars have also supported these claims in their studies wherein they found that positive emotions lead to good academic outcomes whereas negative emotions result in lower performances [24]. Moreover, in the domain of e-learning, positive emotions are higher than negative emotion in synchronous learning activities with the peers and the instructors. Positive emotions during the various stages of e-learning help students to score well, have better learning experience and in maintaining constructive behavioural patterns through the learning process.

Modern perspectives do notice the relationship between emotion and cognition, which in earlier studies were found opposites to each other. Plato, Descartes and Kant have viewed emotion as erratic which hinders rationality and sanity among the individuals $[25,26]$. Distance education as made possible because of technological interventions has renewed interest among the researchers to find relationship between the both. In learning theories, cognition has always been realised playing prime role in any educational settings that Martin and Briggs [27] challenged and suggested that affective and cognitive are the two major domains to be addressed to develop a comprehensive and holistic learning set up. This has proved to be less popular because of the

Образование и наука. Том 22, № 4. 2020/The Education and Science Journal. Vol. 22, № 4. 2020 
nature of affective part of learning. Since there has been a lack of consensus in defining emotion as evident from the multiple perspectives proposed over the last two decades. Unlike the previous studies which mainly focused on the impact of positive and negative emotions in the e-learning process, the present study aims to explore the relationship between EI and the students' readiness for the e-learning.

Leading theories related to EI have conceived the idea of identification and regulation of human sentiments differently which have led to the identification various factors involved in such practice [28]. For instance, Goleman proposed EI as a set of emotional and social competencies that affects behavioural patterns and the nature of their performance whereas Mayer-Salovey [29] defines EI as person's ability to perceive, understand, manage and use emotions to facilitate their thinking and decision making ability. Psychological aspects of learners' readiness for online learning (such as self-directed learning, motivation, learners' control, computer and internet self-efficacy) and psychometric abilities of EI have provided the conceptual framework for this study to further explore the traits of EI and psychological indicators for learners' readiness for e-learning. It has been evident in various studies that EI plays a crucial role in determining the learning experience and positive learning outcomes [30-32]. Academic self-efficacy is perceived as the ability to use digital tools in academic activities, is related to the performance of the students.

\section{Research Questions}

The current research aims to address the following research questions:

a. What is the extent to which the learners are ready to adopt e-learning programmes?

b. What is the extent to which emotional intelligence predicts learners' readiness for such programmes?

\section{Research Methodology}

\section{Sample}

The respondents, 340 students participated in the study, were from the Northern Border University (NBU, hereafter) in Saudi Arabia. Participants were selected randomly from the Rafha campuses during the second semester of the academic year 2018-2019. Both male and female students participated in the study. Data of students enrolled in first, second and third year of the undergraduate programmes in the Faculties of Pharmacy, IT, Arts and Basic Sciences were collected from Rafha (male and female branches) of NBU. Out of total 680 students enrolled in various programmes, 340 study samples were randomly selected from the undergraduate programmes. These identified students were approached with the research tools. They were asked to return 
the filled in questionnaires. 208 students returned their responses and completed their forms that amount to $61.1 \%$ of the total selected samples. Their level of educational was taken as age factor to enhance the variability of the results. Elicited data were compiled in SPSS file for further analysis to answer the research questions.

\section{Research tools}

The current research is based on the idea of learners' readiness for e-learning as proposed by Hung et al. and EI as postulated by Wong and Law [33]. Online learning readiness scale (OLRS, hereafter) consists of subscales; computer/internet self-efficacy (CS), self-directed learning (SL), learners' control (LC), motivation (M) and online communication self-efficacy (OCS). The validity of the scale was checked using Taiwanese college students which demonstrated reliabilities of.74 (CS),.87 (SL),.73 (LC),.84 (M) and.87 (OCS) in the studies of Hung et al. OLRS has been used in various other studies to assess learners' readiness for e-learning [34]. Emotional Intelligence Scale (EIS, hereafter) consists of subscales; self-emotions appraisal (SA), others-emotions appraisal (OA), use of emotions (UE), and regulation of emotions (RE) which reported alpha coefficients of. $87, .83, .84$ and.90 respectively. The scale has been validated on various different samples [35].

\section{Research design and procedure}

Both the scales were developed using five-point Likert scales. For the study purpose and the convenience of the respondents both the scales were simplified and further translated into Arabic language as mostly the respondents are non-native English speakers. Two professors from the area of general education and one from educational psychology were selected to assess the face and content validity of the scales; all the experts were from the reputed institutions of Saudi Arabia. The experts' comments improved a lot the scales and helped me finalising the tools for the study. Further, in pilot study, 20 undergraduate students were asked to indicate if they faced any issues in reading or understanding the tools so as to be sure of the nature and feasibility of the questionnaires. The Cronbach's Alpha values of both the scales and subscales were found. 80 for the final study.

\section{Data Elicitation and Analysis}

\section{Data Set 1}

The generalisations of data for Emotional Intelligence are as under:

a. The data shows that the emotional intelligence of students of 'Pharmacy' faculty is the highest as they have given the maximum positive responses (800). The emotional intelligence of 'Arts' (students) is the lowest as they have given the 
minimum positive responses to the questionnaire (326). If we arrange the degree of emotional intelligence faculty wise then we get the following order:

$$
\text { Pharmacy }>I T>\text { Sciences }>\text { Arts. }
$$

b. The gender wise responses show that the emotional intelligence of female students is greater than the male students. If we arrange the degree of emotional intelligence gender wise then we will get the following order:

$$
\text { Female }>\text { Male }
$$

c. The responses show that the total emotional intelligence (Item 1-6) of female students is greater than the male students. If we arrange the degree of emotional intelligence gender wise then we will get the following order:

$$
\text { Female (Total_Emotional_Intelligence) }>\text { Male (Total_Emotional_Intelligence) }
$$

d. The data shows that the self-emotional appraisal (Item 1-4) of female students is greater than the male students. If we arrange the degree of selfemotional appraisal gender wise then we get the following order:

$$
\text { Female (Total_Self_Emotional_Appraisal) }>\text { Male (Total_Self_Emotional_Appraisal) }
$$

e. The data shows that the regulation of emotions (Item $5-8$ ) of female students is greater than the male students If we arrange the degree of regulation of emotions gender wise then we will get the following order:

$$
\text { Female (Regulation_Of_Emotions) > Male (Regulation_Of_Emotions) }
$$

f. The data shows that the use of emotions (Item 9-11) of male students is greater than the female students If we arrange the degree of use of emotions gender wise then we get the following order:

$$
\text { Male (Use_Of_Emotions) > Female (Use_Of_Emotions) }
$$

g. The data shows that the other emotional appraisal (Item 13-16) of male students is greater than the female students. If we arrange the degree of other emotional appraisal gender wise then we get the following order:

$$
\text { Male (Other_Emotional_Appraisal) }>\text { Female (Other_Emotional_Appraisal) }
$$

\section{Analysis of Data 1}

Faculty wise analysis. It is evident from the data that there is difference in terms of emotional intelligence among all the 4 faculties. To check whether the emotional intelligence really varies amongst the said four faculties or is a just random variation, 'ANOVA' test using the Microsoft Excel in built function 'ANOVA-Single Factor' (table 1) on the positive responses of the students was conducted on each of the four faculties. 
Null hypothesis. The mean positive response of each of the four faculties is the same.

Alternate hypothesis. The mean positive response of each of the faculties is significantly different.

Table 1

ANOVA test on all four faculties

\begin{tabular}{|c|c|c|c|c|c|c|}
\hline \multicolumn{7}{|c|}{ ANOVA: Single Factor } \\
\hline Summary & \multirow{2}{*}{ Count } & Sum & Average & \multirow{2}{*}{\multicolumn{3}{|c|}{ Variance }} \\
\hline Groups & & sum & Average & & & \\
\hline IT & 16 & 720 & 45 & & 540.8 & \\
\hline PHARMACY & 16 & 800 & 50 & & 8.9333333 & \\
\hline SCIENCES & 16 & 480 & 30 & & 0.9333333 & \\
\hline ARTS & 16 & 326 & 20.375 & & 7.5833333 & \\
\hline \multicolumn{7}{|c|}{ ANOVA } \\
\hline $\begin{array}{c}\text { Source } \\
\text { of Variation }\end{array}$ & SS & $d f$ & $M S$ & $F$ & P-value & $F$ crit \\
\hline Between Groups & 8906.6875 & 3 & 2968.895833 & \multirow{3}{*}{7.52452611} & \multirow{3}{*}{0.000235306} & \multirow{3}{*}{2.7581} \\
\hline Within Groups & 23673.75 & 60 & \multirow{2}{*}{394.5625} & & & \\
\hline Total & 32580.4375 & 63 & & & & \\
\hline
\end{tabular}

Since the 'p-Value' i. e. 0.000235306 is less than 0.05 , hence, the mean positive response of the students of each of the said four faculties is significantly different from one another. Now, to assess if the mean positive response of all the four faculties are significantly different from each other or there is a pair of faculty whose mean positive responses are similar and the said variation is random in nature only, t-Test: Two-sample assuming equal variances' (Table 2) on each of the pairs of faculty was conducted using the 'Microsoft-Excel inbuilt function' at 95\% confidence interval level.

Table 2

T-Test: Two-sample assuming equal variances on each pair of faculties

\begin{tabular}{|c|c|c|}
\hline Particulars & Pharmacy & IT \\
\hline Mean & 50 & 45 \\
\hline Variance & 688.9333333 & 540.8 \\
\hline Observations & 16 & 16 \\
\hline Pooled Variance & \multicolumn{2}{|c|}{614.8666667} \\
\hline Hypothesised Mean Difference & \multicolumn{2}{|c|}{0} \\
\hline Df & \multicolumn{2}{|c|}{30} \\
\hline t Stat & \multicolumn{2}{|c|}{0.570327776} \\
\hline $\mathrm{P}(\mathrm{T}<=\mathrm{t})$ one-tail & \multicolumn{2}{|c|}{0.286351279} \\
\hline t Critical one-tail & \multicolumn{2}{|c|}{1.697260887} \\
\hline $\mathrm{P}(\mathrm{T}<=\mathrm{t})$ two-tail & \multicolumn{2}{|c|}{0.572702558} \\
\hline t Critical two-tail & \multicolumn{2}{|c|}{2.042272456} \\
\hline
\end{tabular}


Since the 'p-Value' i. e. 0.572702558 is greater than 0. , hence, the variance of positive response of the students of Pharmacy faculty is not significantly different from the variance of positive response of the students of IT faculty and they all belong to the same population. This could be due to the small sample size.

Table 3

Variance among the four faculties

\begin{tabular}{|l|c|c|}
\hline \multicolumn{1}{|c|}{ Faculties } & p-Value & Difference in variance \\
\hline IT \& Sciences & 0.040086826 & Significant at 95\% confidence interval \\
\hline $\begin{array}{l}\text { Pharmacy \& Scien- } \\
\text { ces }\end{array}$ & 0.013550818 & Significant at 95\% confidence interval \\
\hline Arts \& Sciences & 0.047933123 & Significant at 95\% confidence interval \\
\hline Pharmacy \& Arts & 0.000220547 & Significant at 95\% confidence interval \\
\hline
\end{tabular}

Likewise, similar statistical operations on all the combinations reveal that the 'p-value' for IT, Sciences, Pharmacy and Arts is less than 0.05, hence, the variance of positive response of the students of Sciences, Arts and Pharmacy are significant, i. e. they do not belong to the same population (Table 3).

From the 'ANOVA: Single Factor' test it is very much evident that the mean positive responses are significantly different amongst all the four faculties. However, the variance seems not very much significant between IT and Pharmacy.

\section{Gender wise analysis}

It is evident from the data that there is difference in the emotional intelligence of the male and female students. To check whether the emotional intelligence really varies among the male and female students or it is a just random variation, ANOVA test was conducted using the Microsoft Excel in built function 'ANOVA-Single Factor' on the positive responses of both the male and female students.

Null hypothesis. The mean positive response of each of the male and female student is the same.

Alternate hypothesis. The mean positive response of each male student is significantly different from that of each female student.

Since the p-Value i. e. 0.048804263 is less than 0.05 , hence, the mean positive response of male student is significantly different from that of the female students and they do not belong to the same population. To assess whether the degree of 'Total Emotional Intelligence' is significantly different among the male and female students, 'ANOVA: Single Factor' test was con- 
ducted on the positive responses of each of the students with respect to the first 6 questions of the questionnaire.

\section{Total Emotional Intelligence}

Null hypothesis. The mean positive response of each of the male and female student is the same.

Alternate hypothesis. The mean positive response of each of the male student is significantly different from the mean positive response of each of the female student.

Since the 'p-Value' i. e. 0.046842293 is less than 0.05 , hence, the mean positive response of male student is significantly different from that of female students and they do not belong to the same population. So, the degree of total emotional intelligence in female student is significantly higher than the male students.

To assess whether the degree of 'Total Self-Emotional Appraisal' is significantly different among the male and female students 'ANOVA: Single Factor' test on the positive responses was conducted on each of the students with respect to the first 4 questions of the questionnaire.

\section{Total Self-Emotional Appraisal}

Null hypothesis. The mean positive response of each of the male and female student is same

Alternate hypothesis. The mean positive response of each of the male student is significantly different from that of female student.

Since the 'p-Value' i. e. 0.08814565 is greater than 0.05 , hence, the mean positive response of female student is not significantly different from that of male students and they do belong to the same population. So, the degree of total selfemotional appraisal in female student is similar to the male students with $95 \%$ confidence interval. This could be due to smaller sample size.

\section{Analysis of data 2}

The generalisations of data 2 'Online learning readiness scale (OLRS)' is as under:

Faculty-wise. The representation of responses on OLRS shows that the emotional intelligence of students of Pharmacy faculty is the highest whereas it is the lowest for Arts students. The degree of emotional intelligence facultywise gets the following order:

$$
\text { Pharmacy }>I T>\text { Sciences }>\text { Arts }
$$

Gender-wise. The representation of responses on OLRS shows that the emotional intelligence of female students is greater than that of male students 
across all the four faculties. If we arrange the degree of emotional intelligence gender-wise then we get the following order:

Female (Emotional_Intelligence) $>$ Male (Emotional_Intelligence)

Computer and Self-efficacy. The representation of responses on OLRS shows that the computer and self-efficacy of female students is greater than that of male students. If we arrange the degree of emotional intelligence gender wise then we will get the following order:

$$
\text { Female (Computer\&:Self-Efficacy) }>\text { Male (Computer\&self-Efficacy) }
$$

Self-directed learning. The representation of responses on OLRS shows that the self-directed learning of female students is greater than that of male students. If we arrange the degree of emotional intelligence gender wise then we will get the following order:

\section{Female (Self_Directed_Learning) $>$ Male (Self_Directed_Learning)}

Learner control. The representation of responses on OLRS shows that the self-directed learning of female students is greater than that of male students. If we arrange the degree of emotional intelligence gender-wise then we get the following order:

\section{Female (Learning_Control) $>$ Male (Learning_Control}

Motivation for online learning. The representation of responses on OLRS shows that the motivation for learning in female students is higher than that in male students. If we arrange the degree of emotional intelligence genderwise then we get the following order:

$$
\text { Female (Degree_of_Motivation_For_Learning) }>\text { Male (Degree_of_Motivation_For_Learning) }
$$

Online communication self-efficacy. The tabular and graphical representation of responses on OLRS shows that the online communication self-efficacy in female students is higher than that in male students. If we arrange the degree of emotional intelligence gender wise then we get the following order:

Female (Online_Communication_Self-Efficacy) $>$ Male (Online_Communication_Self-Efficacy)

\section{Analysis of data 2}

Faculty-wise. The emotional intelligence is quite different amongst the four faculties on the 'Online Learning Readiness Scale'. In order to check whether the emotional intelligence really varies amongst all the four faculties or is a just random variation, 'ANOVA' test using the Microsoft Excel in built function 'ANOVA-Single Factor' was conducted on the positive responses of the students of each of the four faculties. 
Null hypothesis. The mean positive response of each of the male and female student is same

Alternate hypothesis. The mean positive response of each of the male student is significantly different from the mean positive response of each of the female student.

Since the 'p-Value' i. e. 5.10118E-23 is less than 0.05, hence, the mean positive response of the students of all faculties is significantly different from one another. To assess whether the mean positive response of all the four faculties on 'OLRS' are significantly different from one another or there is a pair of faculty whose mean positive responses are similar and the said variation is random in nature only, t-Test: Two-sample Assuming equal variances' was conducted on each of the pairs of faculty using the 'Microsoft-Excel inbuilt function' at 95\% confidence interval level.

Table 4

T-Test: Two-sample assuming equal variances

\begin{tabular}{|l|c|c|}
\hline \multicolumn{1}{|c|}{ Particulars } & IT & Pharmacy \\
\hline Mean & 42 & 48.94444444 \\
\hline Variance & 16.23529412 & 18.99673203 \\
\hline Observations & 18 & 18 \\
\hline Pooled Variance & \multicolumn{2}{|c|}{17.61601307} \\
\hline Hypothesised Mean Difference & \multicolumn{2}{|c|}{0} \\
\hline Df & \multicolumn{2}{|c|}{34} \\
\hline t Stat & \multicolumn{2}{|c|}{-4.963693431} \\
\hline P(T<=t) one-tail & $9.57126 \mathrm{E}-06$ \\
\hline t Critical one-tail & 1.690924255 \\
\hline P(T<=t) two-tail & $1.91425 \mathrm{E}-05$ \\
\hline t Critical two-tail & 2.032244509 \\
\hline
\end{tabular}

Since the 'p-Value' i. e. $1.91425 \mathrm{E}-05$ is less than 0.05 , hence, the variance of positive response of the students of Pharmacy faculty is significantly different from the variance that of IT faculty on OLRS and they all belong to the different population.

Table 5

P-value showing difference among faculties

\begin{tabular}{|l|l|l|}
\hline \multicolumn{1}{|c|}{ Faculties } & \multicolumn{1}{c|}{ p-Value } & \multicolumn{1}{c|}{ Difference in variance } \\
\hline Sciences \& IT & $1.06803 \mathrm{E}-05$ & Significant at 95\% confidence interval \\
\hline Pharmacy \& Sciences & $4.41498 \mathrm{E}-12$ & Significant at 95\% confidence interval \\
\hline Arts \& Sciences & $9.83356 \mathrm{E}-06$ & Significant at 95\% confidence interval \\
\hline Arts \& Pharmacy & $1.1739 \mathrm{E}-16$ & Significant at 95\% confidence interval \\
\hline
\end{tabular}


Likewise, the p-Value that is less than 0.05 among all the other faculties, show that the variance is significantly different on OLRS and they do not belong to the same population (Table 3).

\section{Gender-wise}

The data suggests that the emotional intelligence on OLRS is quite different among the male and female students. To check whether the emotional intelligence really varies among the male and female students or is a just random variation, ANOVA test using the Microsoft Excel in built function 'ANOVA-Single Factor' was conducted on the positive responses of both the male and female students.

Null hypothesis. The mean positive response of each of the male and female student is same

Alternate hypothesis. The mean positive response of each of the male student is significantly different from the mean positive response of each of the female student.

Since the 'F-statistic' i. e. 65535 is greater than 'F-Critical' i. e. 4.1300177, hence, it can be concluded that the mean positive response of male student is significantly different from that of female students on OLRS and they do not belong to the same population.

Table 6

Gender-wise OLRS distribution

\begin{tabular}{|l|c|c|l|l|}
\hline \multicolumn{1}{|c|}{ Predictors } & \multicolumn{1}{|c|}{ p-Value } & \multicolumn{1}{|c|}{ Items indicators } & \multicolumn{1}{|c|}{ Male } & Female \\
\hline $\begin{array}{l}\text { Computer and Self-Ef- } \\
\text { ficacy }\end{array}$ & 0.000327486 & $1-3$ Questions & Lower & Higher \\
\hline Self-directed learning & 0.058816848 & $4-8$ Questions & $\begin{array}{l}\text { No difference ob- } \\
\text { served }\end{array}$ \\
\hline Learner Control & 0.000481687 & $9-11$ Questions & Lower & Higher \\
\hline Motivation of Learning & 0.005896151 & $12-14$ Questions & Lower & Higher \\
\hline $\begin{array}{l}\text { Online communication } \\
\text { self-efficacy }\end{array}$ & 0.005896151 & $15-17$ Questions & Lower & Higher \\
\hline
\end{tabular}

ANOVA: Single Factor test revealed that $\mathrm{p}$-Value for all the variables on OLRS is less than 0.05 , hence, it can be concluded that the mean positive response of male student is significantly different from that of the female students and they do not belong to the same population. So in computer and selfefficacy, learners' control, motivation of learning and online communication selfefficacy, female students have higher emotional intelligence than the male students, except self-directed learning wherein no difference was observed. A little bigger data size would be needed to further explore this factor. It can be 
concluded that the emotional intelligence is different in terms of faculties as well as gender. The degree of emotional intelligence was found to be the highest among the Pharmacy students and least among the Arts students. Further, the degree of emotional intelligence was found higher in female students than in male students. The same results were found on 'Online Learning Readiness Scale' where it was found that students of Pharmacy faculty were most active and the students of Arts faculty were the least active. Similarly, the female students were more active on OLRS than the male students.

\section{Discussion}

To investigate the relationship of emotional intelligence with various academic faculties is quite a new area of exploration in educational circles. Classically, readiness for online learning was seen as competence of using technology in most of the scientific enquiries so psychomotor aspects of students were explored in order to assess their preparedness for e-learning. But this research is slight different in its approach as it assessed the psychometric aspects of students' readiness variance and to what extent emotional intelligence does play a significant role in explain this variance.

After examining the four aspects in terms of students' preparedness for e-learning, it was found that students (males and females) had relatively stronger readiness in all the aspects except self-directed learning. Students' responses reveal that IT and Pharmacy students showed better ability in online learning than the Arts and Sciences students. The students reported very encouraging higher abilities in terms of computer/internet self-efficacy and learners' control are higher than online communication; however, self-directed and motivation for online learning were relatively higher among across the sample. The results indicate a different perspective from the findings of Hung et al. who reported that Taiwanese students' readiness was higher in online communication and computer/internet self-efficacy than learners' control and self-directed learning. Buzdar et al. [36] conducted a similar study on Pakistani students, reported average learners' ability of learners' control and lower online communication and computer/internet self-efficacy among the sample.

The findings of the present study confirm a similar situation in terms of online communication self-efficacy. Motivation is found to be higher in both the studies and the present study also confirms the same in Saudi context. In line with Buzdar's et al. [36] observation motivation for learning and self-directed learning were the found to be strong among the Saudi learners as well. Since online learning is not encouraged and implemented in Saudi context,

Образование и наука. Том 22, № 4. 2020/The Education and Science Journal. Vol. 22, № 4. 2020 
the low levels of their online communication self-efficacy is quite understandable; however, maximum internet use in Saudi context reflect on the higher computer/internet self-efficacy of the learners [37]. Lower online learning practices among the Saudi learners is consistent with Valtonen's et al. and Buzdar's et al. findings, who reported that Pakistani and Finnish learners lack experience in e-learning at school and university level, which eventually is reflected in their inadequate preparedness for e-learning. This led to the exploration of the implications of psychometric traits of students, of which EI is considered to be a significant factor in learners' achievement in formal as well as non-formal educational contexts [38]. Since Aliakbari and Abol-Nejadian [39] have already established relationship between EI and learning styles, online learning is regulated by emotions as a crucial factor, the present research formed the basis on these fundamental aspects of effective learning. Statistically, it is evident from the data that EI is directly related to the learners' readiness for e-learning. EI is different among all the four faculties as well as among the gender. The degree of emotional intelligence was found to be highest among the Pharmacy students and least among the Arts students. Further, the degree of EI was found higher in female students than in male students. The same results were found on OLRS where it was found that students of Pharmacy faculty were most active and the students of Arts faculty were least active. Similarly, the female students were more active on OLRS than male students. Emotional traits like use and regularisation of emotions, and self and others' emotional appraisals can be inculcated among the learners by adopting the best pedagogical practices [40, 41]. Various effective approaches of instructions have been identified for social and emotional learning, by making the learners aware of how to regulate their emotions constructively in their educational experience [42, 43].

Pharmacy and IT students are higher in merit than the Sciences and Arts students in their aptitude test conducted before they start their college education. Based on their performance in the test, the students are recommended for further specialisation in their Bachelors degree programme. This might be a reason Pharmacy and IT students are more academics oriented and are open to new developments in educational set up to have a better and effective learning experience. Moreover, humanities and basic science education is yet to be given due status, in terms of job opportunities as well as variety of other purposes. The learners are not well aware of their educational needs and the new pedagogical tools to enhance their learning experience. Raising EI and regulating their sentiments should be an integral part of curriculum to prepare them for online learning; there are various interventions sug- 
gested for emotional learning by Merrell and Gueldner. How effectively these interventions can be implemented in the socio-cultural contexts of Saudi Arabia, should be an area to be further explored in detail.

\section{Conclusions}

The study concludes that students considered for the present study are not fully prepared to take up online learning. The students demonstrated higher readiness for self-directed learning and motivation for learning; however, the results reveal that computer/internet self-efficacy and learners control is quite encouraging too but online communication self-efficacy show their lesser preparedness for online learning. The female students showed better preparedness for online learning than the male students across the four faculties, though due to gender segregation and other societal norms male students enjoy little freedom of choices. However, OLRS results in general verify lower readiness for online learning in Saudi context. EIS predicted the extent EI influence learners' preparedness for online learning. It can be concluded, based on analysis, that EI has considerable effects on learners' preparedness for online learning. T-test (two-sample assuming equal variances) indicated that Pharmacy and IT students showed higher total emotional intelligence than Sciences and Arts irrespective of their gender. Moreover, the same sample recorded higher readiness for online learning. The results of this study open up a dimension to improvise the pedagogical strategies in order to inculcate equality in educational awareness of students across the faculties so that learning objectives can be achieved in a real sense.

\section{References}

1. Miceli M., Castelfranchi C. Expectancy and emotion. Oxford: OUP; 2014.

2. D'Errico F., Paciello M. Cerniglia L. When emotions enhance students' engagement in e-learning processes. Journal of e-Learning and Knowledge Society [Internet]. 2016 [cited 2020 Jan 08]; 12 (4): 9-23. Available from: https://www.learntechlib.org/p/173676/

3. D'Amico A. The use of technology in the perception of children's emotional intelligence: The multimedia program "Developing Emotional Intelligence". International Journal of Emotional Research. 2018; 10 (1): 47-67.

4. Feidakis M., Daradoumis T., Caballé S., Conesa J. Embedding emotion awareness into e-learning environments. International Journal of Emerging Technologies in Learning (iJET). 2014; 9 (7): 39.

5. Artino A. Emotions in online learning environments: Introduction to the special issue. The Internet and Higher Education. 2012; 15 (3): 137-140.

6. Castelfranchi C. Affective appraisal versus cognitive evaluation. Affective interactions: Towards a new generation of computer interfaces. Ed. by $\mathrm{Pa}-$ iva A. Heidelberg: Springer; 2001. p. 76-106.

Образование и наука. Том 22, № 4. 2020/The Education and Science Journal. Vol. 22, № 4. 2020 
7. Merrell K. W., Gueldner B. A. Social and emotional learning in the classroom: Promoting mental health and academic success. New York: Guilford Press; 2010 .

8. Guarnera M., D'Amico A. Training of attention in children with low arithmetical achievement. Europe's Journal of Psychology. 2014; 10 (2): 277-90.

9. Barbadet J. Emotion, social theory and social structure. Cambridge: Cambridge University Press; 2019.

10. Durlak J., Weissberg R., Dymnicki A., Taylor R., Schellinger K. The impact of enhancing students' social and emotional learning: A meta-analysis of school-based universal interventions. Child Development. 2011; 82 (1): 405-432.

11. Jones S., Brush K., Bailey R., Brion-Meisels G., McIntyre J., Kahn J., et al. Navigating SEL from the inside out. Looking inside and across 25 leading SEL programs: A practical resource for schools and host providers. Cambridge MA: Harvard Graduate School of Education; 2017.

12. New vision scale for children - fostering social and emotional learning through technology [Internet]. 2016 [cited 9 Jan 2020]. Available from: http://www3.weforum.org/docs/WEF_New_Vision_for_Education.pdf

13. D'Amico A., Guastella D. Robotics construction kits: From "objects to think with" to "objects to think and to emote with". Future Internet. 2018; 10 (2): 21.

14. Jordan K. Initial trends in enrolment and completion of massive open online courses. International Review of Research in Open and Distributed Learning. 2014; 15 (1): 133-160.

15. Ferro T. The influence of affective processing in education and training. New Directions for Adult and Continuing Education. 1993; (59): 25-33.

16. Smith P. J. Learning preferences and readiness for online learning. Educational Psychology. 2005; 25 (1): 3-12.

17. Smith P. J., Murphy K. L., Mahoney S. E. Towards identifying factors underlying readiness for online learning: An exploratory study. Distance Education. 2003; 24 (1): 57-67.

18. Lynch MMV. How to be a successful distance learning student: Learning on the internet. New York: Pearson Custom Publishing; 2001.

19. Hung M.-L., Chou C., Chen C.-H., Own Z.-Y. Learner readiness for online learning: Scale development and student perceptions. Computers \& Education. 2010; 55 (3): 1080-90.

20. Valtonen T., Kukkonen J., Dillon P., Väisänen P. Finnish high school students' readiness to adopt online learning: Questioning the assumptions. Computers \& Education. 2009; 53 (3): 742-748.

21. Cleveland-Innes M., Campbell P. Emotional presence, learning, and the online learning environment. International Review of Research in Open and Distributed Learning. 2012; 13 (4): 269.

22. Scherer K. R. Psychological models of emotion. Ed. by J. C. Borod. The Neuropsychology of Emotion. New York: Oxford University Press; 2014. p. 137-162.

23. D'Errico F., Poggi I. Social emotions. A challenge for sentiment analysis and user models. Emotions and personality in personalized services. Ed. by Tkalcic M., De Carolis B., de Gemmis M., Odic A., Košir A. Springer; 2016. p. 13-34. 
24. Pekrun R., Goetz T., Frenzel A. C., Barchfeld P., Perry R. P. Measuring emotions in students' learning and performance: The Achievement Emotions Questionnaire (AEQ). Contemporary Educational Psychology. 2011; 36 (1): 36-48.

25. Dirkx J. The power of feelings: Emotion, imagination, and the construction of meaning in adult learning. New Directions for Adult and Continuing Education. 2001; 2001 (89): 63.

26. Frijda N., Manstead A., Bem S. The influence of emotion on beliefs. In: Emotions and Beliefs: How feelings influence thoughts. Cambridge: Cambridge University Press; 2000.

27. Martin B., Briggs L. The affective and cognitive domains: Integration for instruction and research. Englewood Cliffs: Educational Technology Publication; 1986.

28. Neophytou L. Emotional intelligence and educational reform. Educational Review. 2013; 65 (2): 140-54.

29. Mayer J. D, Salovey P., Caruso D. R. Emotional intelligence: New ability or eclectic traits? American Psychologist. 2008; 63 (6): 503-17.

30. Liu R.-D., Zhen R., Ding Y., Liu Y., Wang J., Jiang R., et al. Teacher support and math engagement: Roles of academic self-efficacy and positive emotions. Educational Psychology. 2017; 38 (1): 3-16.

31. Richardson M., Abraham C., Bond R. Psychological correlates of university students' academic performance: A systematic review and meta-analysis. Psychological Bulletin. 2012; 138 (2): 353-87.

32. Martinez M. Key Designs consideration for personalized learning from experience. Ed. by Boud D., Cohen R., Walker D. Using experience for learning, Buckingham: SRHE \& Open University Press; 2001. p. 1-8.

33. Wong C.-S., Law K. S. The effects of leader and follower emotional intelligence on performance and attitude. The Leadership Quarterly. 2002; 13 (3): 243-74.

34. Çiftci S., Güneş E., Üstündağ M. Attitudes of distance education students towards web based learning - a case study. Procedia - Social and Behaviou ral Sciences. 2010; 2 (2): 2393-2396.

35. Bao X., Xue S., Kong F. Dispositional mindfulness and perceived stress: The role of emotional intelligence. Personality and Individual Differences. 2015; 78: 48-52.

36. Buzdar M., Ali A., Tariq R. Emotional intelligence as a determinant of readiness for online learning. The International Review of Research in Open and Distributed Learning. 2016; 17 (1): 148-158.

37. Communication and Information Technology Commission (CITC). Internet Usage in the Kingdom of Saudi Arabia (Report on Education Sector) [Internet]. 2017 [cited 2020 Jan 08]. Available form: https://www.citc.gov.sa/en/mediacenter/annualreport/Documents/PR_REP_013Eng.pdf

38. Berenson R., Boyles G., Weaver A. Emotional intelligence as a predictor of success in online learning. The International Review of Research in Open and Distributed Learning. 2008; 9 (2): 1-17.

39. Aliakbari M., Abol-Nejadian R. Trait emotional intelligence and learning styles: The case of Iranian English for academic purposes learners. Educational Psychology. 2013; 35 (7): 779-793. 
40. Chung S., McBride A. Social and emotional learning in middle school curricula: A service learning model based on positive youth development. Children and Youth Services Review. 2015; 53: 192-200.

41. Abdolrezapour P., Tavakoli M. The relationship between emotional intelligence and EFL learners' achievement in reading comprehension. Innovation in Language Learning and Teaching. 2012; 6 (1): 1-13.

42. Bar-On R., Maree K., Elias M. Educating people to be emotionally intelligent. Westport, Conn.: Praeger Publishers; 2007.

43. Wong C.-S., Law K. S. The effects of leader and follower emotional intelligence on performance and attitude: An exploratory study. The Leadership Quarterly. 13 (3): 243-274.

\section{Information about the author:}

Ahmed M. Alenezi - Associate Professor, Department of Instructional Technology, College of Education, Northern Border University, Arar, Saudi Arabia. E-mail: ahmed.alenezi@nbu.edu.sa

Received 12.12.2019; accepted for publication 11.03.2020.

The author has read and approved the final manuscript.

\section{Информация об авторе:}

Ахмед Маджун А^енези - доцент кафедры педагогических технологий педагогического комледжа Северного пограничного университета, Арар, Саудовская Аравия. E-mail: ahmed.alenezi@nbu.edu.sa

Статья поступила в редакцию 12.12.2019; принята в печать 11.03.2020. Автор прочитал и одобриц окончательный вариант рукописи. 